\title{
A strange presentation of molluscum contagiosum in an immunocompetent child
}

\section{Khadija Elboukhari, Kaoutar Achehboune, Sara Elloudi, Hanane Baybay, Fatima Zahra Mernissi}

Departement of Dermatology, University Hospital of Fez, Morocco

Corresponding author: Dr. Khadija Elboukhari, E-mail: elboukharikhadija89@gmail.com

Sir,

An eight years child with an antecedent of atopic dermatitis, consulted for an eruption occurring since a month ago, in the trunk, without pruritus or pain. When we examined him, we discovered a strange linear eruption of the trunk, well demarcated. Closer examination found a confusing translucid and non-erythematous papules like small pearls (Fig. 1). The diagnosis of Molluscum Contagiosum was then evocated, and dermoscopy confirmed it by showing a peripheral vascularization of the papules with a withe central amorphous substance (Fig. 2).

The patient has been treated by potassium hydroxide 5\% twice a day with a spectacular improvement after two weeks (Fig. 3).

First described in 1871 by batman [1], Molluscom contagiosum is caused by a poxvirus, which can be transmitted by casual, sexual contact or selfcontamination. Its prevalence in children is about 5.1\%-11.5\% [2]. Clinically it appears like a shiny papules or minipapules with a diameter between 2 and $5 \mathrm{~mm}$. The central umbilication is pathognomonic and its localization concern commonly the face, trunk, and extremities. However, Molluscum contagiosum can have an atypical presentation, more frequently when there is an immunodepression condition such as: AIDS (acquierd immunodeficiency syndrome), Viskott Aldrich Disease, malignant lymphoma [3], and it can appear larger (more than $1 \mathrm{~cm}$ ), eczematous or abscessed and sometimes refractory to the usual treatment [4]. In the literature, the linear presentation has been reported in one case of a new born who

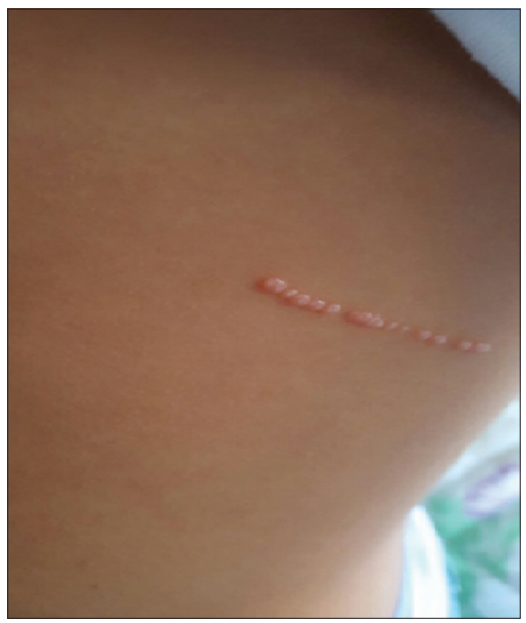

Figure 1: Linear adjenced shiny papules in the left part of trunk.

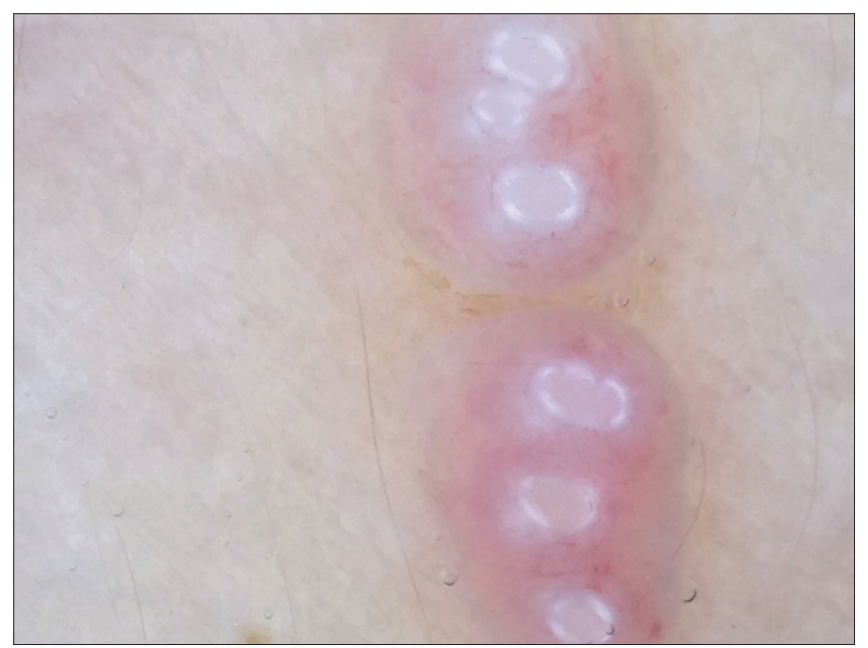

Figure 2: Central white, yellow structure and Crown peripherel vessels seen by dermoscopy.

had a a unique linear plaque composed of many small molluscum papules on the coccygeal region

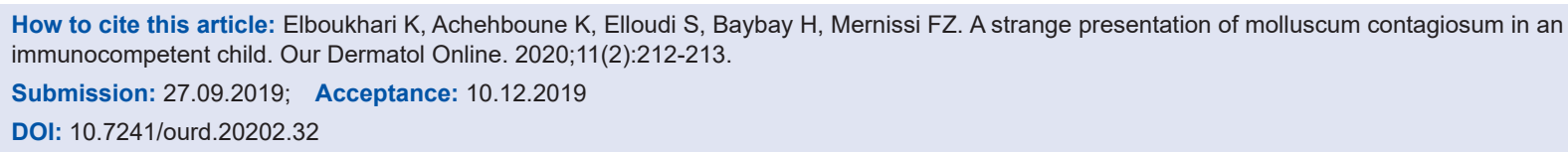




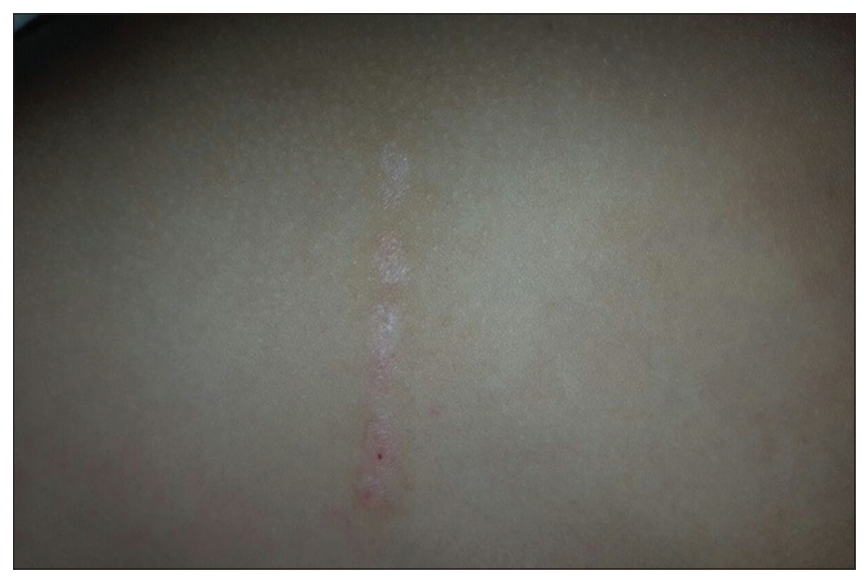

Figure 3: Dissolve of the linear papular eruption after treatment by potassium hydroxide.

present since birth [5]. In our patient, the linear distribution was confusing us and other diagnosis was evocated such are linear epidermal nevus and contact dermatitis. Finally, the dermoscope make the diagnosis by revealing specifics dermoscopy signs of Molluscum contagiosum such are: white-to-yellow polylobular structures and crown vessels seen in (Polarized-light dermoscopy [6].

The spectacular improvement after using potassium hydroxide is a diagnostic criteria, this alkaline compound dissolves the keratin and destroy the skin lesion by inducing an inflammatory reaction [7].

\section{ACKNOWLEDGEMENTS}

We are indebted to the patient and his parents for giving us the consent for the publication

\section{REFERENCES}

1. Meirowsky E, Keys S, Behr G. Cytology of molluscum contagiosum, with special regard to significance of so-called vacuoles. J Invest Der-matol.1946;7:165-9.

2. Olsen JR, Gallacher J, Piguet V, Francis NA. Epidemiology of mollus-cum contagiosum in children: a systematic review. Fam Pract. 2014;31:130-6.

3. Vardhan P, Goel S, Goyal G, Kumar N. Solitary giant molluscum con-tagiosum presenting as lid tumor in an immunocompetent child. Indian J Ophthalmol. 2010;58:236-8.

4. Basu S, Kumar A. Giant molluscum contagiosum - a clue to the diagnosis of human immunodeficiency virus infection. J Epidemiol Glob Health. 2013;3:289-91.

5. Ujiie H, Aoyagi S, Hirata Y, Osawa R, Shimizu H. Linear congenital molluscum contagiosum on the coccygeal region. Pediatr Dermatol. 2013;30:e83-4.

6. Meza-Romero R, Navarrete-Dechent C, Downey C. Molluscum contagiosum: an update and review of new perspectives in etiology, diagnosis, and treatment. CCID. 2019;12:373-81.

7. Gerlero P, Hernandez-Martin A. Update on the treatment of mollus-cum contagiosum in children. Actas Dermosifiliogr. 2018;109:408-15.

Copyright by Khadija Elboukhari, et al. This is an open access article distributed under the terms of the Creative Commons Attribution License, which permits unrestricted use, distribution, and reproduction in any medium, provided the original author and source are credited. Source of Support: Nil, Conflict of Interest: None declared. 